\title{
TEKNIK PERSUASIF DALAM BUKU SUKSES TANPA GELAR KARYA ANDRIAS HAREFA
}

\author{
Nina Kartika Sari \\ ninakartikasarii@gmail.com
}

\begin{abstract}
This re search entitled persuasive techniques in a sussessful book without the title of Andrias Harefa work. The problem of research, how persuasive techniques, rationalization, identification, suggestion, conformity, compensation, replacement and projection in a successful book without a degree of work Andrias Harefa? Aims to describe, analyze, and intepret persuasive techniques, rationalization, identification, suggestion, conformity, compensation, replacement and projection in a successful book without the title of work Andrias Harefa. This research uses the theory proposed by Gorys Keraf 2004, using descriptive method. Data and data sources in this study is the contents of a successful book without the title Andrias Harefa work in 2005. This research method descriptive method, research type that is literature, and research approach that is qualitative. Data collection techniques used by the author is to classify data, analyze data, interpret data, and draw conclusions. Result of research about persuasive technique in success book without title of work of Andrias Harefa found existence persuasive technique counted 47 data or equal to $100 \%$ of them, rationalization used Andrias Harefa equal to 3 data or egual to $7 \%$, identification used Andrias Harefa 31 data or equivalent to $67 \%$, the suggestion used Andrias Harefa of 3 data or equaivalent to $7 \%$, the conformity used Andrias Harefa as much as 3 data or equivalent to $7 \%$, replacement used Andrias Harefaas many as 4 data or equivalent to $9 \%$, the projection used Andrias Harefa as much as 1 data or equivalent to $2 \%$. Thus it can be concluded that the persuasive technique used by Andrias Harefa in a successful book without a title is more dominant using the technique of persuasive identification because a successful book without the title of work Andrias Harefa tends to use spsesial and interesting things to influence the reader, followed by replacemet, rationalization, suggestion, conformity, compensation, and projection.
\end{abstract}

Keywords: Sukses Tanpa Gelar book, persuasif techniques

\begin{abstract}
ABSTRAK
Penelitian ini berjudul "Teknik Persuasif dalam buku Sukses Tanpa Gelar Karya Andrias Harefa". Masalah penelitian bagaimanakah teknik persuasif (1) rasionalisasi, (2) identifikasi, (3) sugesti, (4) konformitas, (5) kompensasi, (6) penggantian, dan (7) proyeksi dala buku Sukses Tanpa Gelar karya Andrias Harefa? Bertujuan untuk mendeskripsikan, menganalisis, dan menginterprestasikan, teknik persuasif (1) rasionalisasi, (2) identifikasi, (3) sugesti, (4) konformitas, (5) kompensasi, (6) penggantian, dan (7) proyeksi dalam buku Sukses Tanpa Gelar karya Andrias Harefa. Penelitian ini menggunakan teori yang dikemukakan oleh Goris Keraf (2004), dengan menggunakan metode deskriptif. Sumber data dan data pada penelitian ini yaitu isi buku Sukses Tanpa Gelar Karya Andrias Harefa tahun 2005. Metode penelitian ini metode deskritif, jenis penelitian yaitu kepustakaan, dan pendekatan penelitian yaitu kualitatif. Teknik pengumpulan data yang digunakan penulis adalah mengklasifikasi data, menganalisis data, menginterpretasikan data dan menarik kesimpulan. Hasil penelitian tentang teknik persuasif dalam buku Sukses Tanpa Gelar karya Andrias Harefa ditemukan adanya teknik persuasif sebanyak 40 data atau setara dengan $100 \%$ dianatarnya (1) rasionalisasi yang digunakan Andrias Harefa sebanyak 3 data atau setara dengan $7 \%$, (2) identifikasi yang digunakan Andrias Harefa sebanyak 31 data atau setara dengan 67\%, (3) sugesti yang digunakan Andrias Harefa sebanyak 3 data atau setara dengan 7\%, (4) konformitas yang digunakan Andrias Harefa sebanyak 3 data atau setara dengan 7\%, (5) kompensasi yang digunakan Andrias Harefa sebanyak 2 data atau setara dengan 4\%, (6) penggantian yang digunakan Andrias Harefa sebanyak 4 data atau setara dengan 9\%, (7) proyeksi yang digunakan Andrias Harefa sebanyak 1 data atau setara dengan $2 \%$. Jadi, dapat disimpulkan bahwa teknik persuasif
\end{abstract}


yang digunakan oleh Andrias Harefa dalam buku Sukses Tanpa Gelar lebih dominan menggunakan teknik persuasive identifikasi karena buku Sukses Tanpa Gelar Karya Andrias Harefa cenderung menggunakan hal-hal yang khusus dan menarik untuk mempengaruhi pembaca, diikuti penggantian, rasionalisasi, sugesti, konformitas, kompensasi dan proyeksi.

\section{Kata Kunci: buku Sukses Tanpa Gelar, teknik persuasif}

\section{PENDAHULUAN}

Teknik persuasif merupakan sarana berkomunikasi untuk membujuk seseorang. Persuasif sebagai bentuk usaha untuk membentuk pola pikir antara pembicara dan pendengar. Persuasif mengubah atau memengaruhi prilaku seseorang untuk mengikuti sesuai dengan yang diharapkan oleh pembicara. Teknik persuasif di bentuk oleh dua suku kata (1) persuasi merupakan ajakan seseorang atau mengajak melalui bujukan (2) imbuhan if- memiliki makna ajakan. Jadi, persuasif merupakan aktivitas mengajak seseorang melalui bujukkan. Menurut Keraf (2004:124) menyatakan, "Persuasif adalah suatu seni verbal yang bertujuan untuk meyakinkan seseorang agar melakukan sesuatu yang dikehendaki pembicara pada waktu ini atau pada waktu yang akan datang".

Persuasif sebagai upaya untuk memengaruhi seseorang memerlukan cara atau teknik. Teknik merupakan strategi yang digunakan untuk mencapai maksud tertentu. Teknik persuasif merupakan gabungan dua unsur: teknik dan persuasif. Teknik persuasif adalah strategi memengaruhi pola pikir agar pesan yang disamapaikan dapat diterima oleh pendengar. Teknik persuasif bagian dari retorika. Retorika suatu istilah yang digunakan untuk menyusun kata-kata dengan baik.

Retorika sebagai ilmu menggunakan kata-kata diperlukan untuk menyampaikan pesan pada komunikan. Retorika adalah suatu istilah yang secara tradisional diberikan pada suatu teknik pemakaian bahasa sebagai seni, yang didasarkan pada suatu pengetahuan yang tersusun baik. Retorika juga diartikan sebagai kesenian untuk berbicara baik, yang dipergunakan dalam proses komunikasi antarmanusia. Menurut Rakhmat (2011:2) "Retorika adalah bidang studi komunikasi yang telah berumur tua, disamping menunjukan tempatnya yang layak dalam perkembangan ilmu komunikasi”. Jadi, retorika adalah membina saling pengertian yang mengembangkan kerjasama dalam menumbuhkan kedamaian dalam kehidupan bermasyarakat melalui kegiatan bertutur.

Retorika sesungguhnya adalah bagian dari disiplin ilmu komunikasi, karena dalam retorika terdapat penggunaan simbol-simbol yang dilakukan oleh manusia. Retorika erat hubungannya dengan persuasi. Persuasi adalah strategi pengelolaan kata-kata untuk meningkatkan kepercayaan pendengar. Sehingga persuasi berperan penting dalam penggunaan retorika. Retorika adalah seni dari mengkontruksikan argumen. Menurut Abidin (2013:53) "Retorika adalah teknik pembujukrayuan secara persuasi untuk menghasilkan bujukan melalui karakter pembicara, emosional, atau argumen". Maka semakin bagus retorika yang dijalankan, semakin menunjukkan keluarbiasaan pembicaranya.

Retorika merupakan keterampilan berbicara untuk meyakinkan khlayak, melalui seni berbicara dengan berkomunikasi. Faizah (2007:1) menyatakan bahwa dewasa ini retorika diartikan sebagai kesenian untuk berbicara baik, yang digunakan dalam proses komunikasi antar manusia. Selanjutnya, Abidin (2013:58) menyatakan bahwa tujuan retorika adalah persuasif, untuk meyakinkan pendengar akan kebenaran gagasan yang dibicarakan. Dengan arti lain, retorika tidak akan terpisah dengan istilah komunikasi. Komunikasi pada hakikatnya berfungsi untuk menyampaikan informasi, gagasan, ide dan keinginan dengan menggunakan kata-kata. Holavand dalam Suhandang (2009:14) menyatakan bahwa komunikasi adalah proses seorang insan (komunikator) menyampaikan rangsangan (biasanya berupa lambang dalam bentuk kata-kata) untuk merubah prilaku insan lainnya. Dari kacamata komunikasi tampak bahwa retorika merupakan proses penyampaian pesan yang sering disebut sebagai seni berbicara. Retorika memberikan 
peran yang sangat penting dalam setiap keterampilan berbahasa, khususnya berbicara.

Teknik persuasif adalah hal pokok dalam berkomunikasi karena teknik persuasif bersifat mempengaruhi. Suhandang (2009:160) menyatakan bahwa persuasif adalah kegiatan psiokologi dalam usaha mempengaruhi pendapat, sikap, sifat dan prilaku orang atau orang banyak. Keraf (2004:124) menyatakan bahwa teknik persuasif dibedakan ,menjadi tujuh, yaitu (1) rasionalisasi (2) identifikasi (3) sugesti (4) konformitas (5) kompensasi (6) penggantian (7) proyeksi. Ketujuh teknik persuasif tersebut digunakan komunikator mempengaruhi pembaca, atau pendengar. Kemampuan menerapkan teknik persuasif yang digunakan penulis dalam buku memiliki peran yang sangat penting dengan menerapkan teknik persuasif seorang penulis dapat meyakinkan atau memengaruhi pembacanya. Sebaliknya jika penulis tidak menggunakan teknik persuasif, maka penulis tidak akan bisa meyakinkan pembaca buku tersebut. Buku Sukses Tanpa Gelar Karya Andrias Harefa juga terdapat kalimat yang mengandung teknik persuasif, salah satu contoh teknik rasionalisasi sebagai berikut: Waktu itu, tahun 1982, perempuan yang lahir 15 januari 1965 ini, baru duduk di kelas dua SMAN 1 yogyakarta. Ia pun dinyatakan drop out. Dan sebuah perjalanan hidup yang unik pun dimulai.(Harefa, 2005, SST).

Data ID/2/43/1/2 merupakan teknik persuasif identifikasi. Menurut Depdiknas identifikasi merupakan tanda kenal diri dan bukti diri. Andrias Harefa mengidentifikasi tanda kenal dirinya kepada pembaca. Bukti identifikasi pada kutipan di atas ialah Waktu itu, tahun 1982, perempuan yang lahir 15 januari 1965 ini, baru duduk di kelas dua SMAN 1 yogyakarta.Kalimat yang tercetak miring berkaitan dengan identifikasi yang berisi tanda kenal diri penulis.

Kalimat dalam buku Sukses Tanpa Gelar karya Andrias Harefa pada Bab 1 halaman 43 pada paragraf ke-1 Andrias HerafaWaktu itu, tahun 1982, perempuan yang lahir 15 januari 1965 ini, baru duduk di kelas dua SMAN 1 yogyakarta. Kalimat yang tercetak miring berkaitan dengan identifikasi yang berisi tanda kenal diri penulis. Hal ini sesuai dengan Keraf (2004:124) menyatakan
Persuasi berusaha menghindari situasi konflik dan sikap ragu-ragu, maka seorang komunikator harus mampu menganalisa komunikannya dan seluruh situasi yang dihadapinya dengan benar. Dengan menganalisa komunikanya maka komunikator dengan mudah mengidentifikasi adalah tanda kenal diri, penentu identitas seseorang atau benda, dan proses psiokologi yang terjadi pada diri seseorang karena secara tidak sadar dia membayangkan dirinya seperti orang yang dikaguminya, lalu dia meniru tingkah laku orang yang dikaguminya itu.

Sehubung dengan teknik persuasif yang bersifat mempengaruhi. Penulis memilih objek yaitu Buku Sukses Tanpa Gelar Karya Andrias Harefa, berdasarkan pemahaman penulis terhadap buku Sukses Tanpa Gelar menggunakan ketujuh teknik persuasif yang dikemukakan oleh Keraf. Teknik persuasif yang dimaksud adalah rasionalisasi, identifikasi, sugesti, konformitas, kompensasi, penggantian, proyeksi, di dalam buku Sukses Tanpa Gelar Karya Andrias Harefa tersebut.

Buku Sukses Tanpa Gelar karya Andrias Harefa pertama kali terbit tahun 1998 ini, pembaca akan menemukan lima belas kisah. Edisi awalnya hanya berisi tujuh kisah dengan tokoh-tokoh yang sangat inspiratif. Mereka telah melewati proses yang luar biasa sulit, namun berhasil membangkitkan roh keberhasilan di dalam dirinya. Menembus badai-badai penderitaan, mereka berproses dan menemukan jati dirinya sebagai ciptaan tuhan yang luar biasa. Kecuali Lincoln, mereka semua dipilih terutama karena bisa berhasil meraih Sukses Tanpa Gelar akademis. Ada yang tidak tamat sekolah dasar, ada yang hanya lulus sekolah menengah atas, dan ada yang drop out dari universitas. Lewat pemaparan yang singkat namun mengena, kisah tokoh-tokoh tersebut bisa memberikan gairah dan optimisme bagi siapa saja yang ingin meraih sukses dengan atau tanpa gelar.

Andrias Harefa merupakan sosok pria kelahairan tahun 1964. Pria berdarah Nias yang lahir di Curup, Bengkulu, ini bukan hanya penulis buku-buku motivasi, tetapi juga dikenal sebagai pembicara inspirasional. Ia sering diundang untuk berbicara dalam forum employee gathering, annual conference, regional conference, national convention, 
rapat kerja perusahaan, dan seminar-seminar nasioanl yang dihadiri ratusan hingga ribuan orang. Andrias Harefa merupakan sosok pria atau seorang yang termasuk orang yang percaya bahwa, bila mempelajari kebenaran dan tidak mengalami perubahan hidup, maka hanya ada dua kemungkinan kita tidak sungguh-sungguh belajar atau yang kita pelajari bukan kebenaran.

Buku ini sangat menginspirasi bagi siapa saja yang membacanya tentang kisahkisah sukses dengan tokoh-tokoh yang inspiratif. Tidak mengajak hanya menceritakan. Bukan mengguruhi tapi memberi contoh dari pengalaman. Cara menulis yang mudah dimengerti memudahkan pembaca khususnya para pelajar seperti saya yang masih awam. Buku best seller yang covernya berubah, bentuk buku yang kecil dengan edisi yang di perkaya. Buku dengan sampul yang sudah direvisi dengan beragam warna dengan sampul menulis laris di toko buku.Buku yang menarik banyak orang untuk membacanya. Berikut ini beberapa review singkat dari biografi Andrias Harefa yang diluncurkan sejak September 1998, bukubukunya mulai diterbitkan oleh PT Gramedia Pustka Utama (GPU). Kelebihan dari buku ini adalah (1) ditulis oleh seorang Manusia Pembelajar, Penulis Buku Terlaris, Fasilitator Pelatihan, atau Pembicara Motivasional yang unik dan produktif. Narasi yang ditulis mengalir dengan baik. Ketika membaca buku ini kita tidak serasa dipaksa terjun menelusuri kehidupan seorang tokoh ditulis, ( 2) cerita yang digalu dengan baik kita dapat memahami bagaimana latar belakang Andrias Harefa, perjalanannya merintis usaha hingga menjadi yang terbaik di sektor usahanya yang disebut sebagai salah satu penulis buku-buku best seller di Indonesia, (3) beberapa 'rahasia' kesuksesan dirinya sebagai pengusaha papan atas. Setidaknya bakat 'sukses' itu bisa diasah sejak awal baik ketika masih sekolah, kuliah dan pentingnya kerja keras. Andrias Harefa sudah melakukan banyak kegiatan kemahasiswaan yang menjadi batu pijakannya menjadi seorang pemimpin bisnis yang hebat, (4) buku ini selain berisi jejak perjalanannya dalam berkarir juga ada pencapaianpencapaian yang dilakukan untuk Indonesia. Tidak terlambat untuk melihat dan membaca buku ini.Sukses Tanpa Gelar di rekomendasikan untuk dibaca oleh semua kalangan. Dari anak muda yang ingin mendapat inspirasi menjadi seorang enterprenuer, guru yang ingin memberi cerita untuk para siswanya tentang kerja keras tidak akan sia-sia, penikmat buku biografi. Selamat membaca.

Berdasarkan dasar pemikiran dan gejala-gejala yang dikemukakan, dan diperkuat oleh komentar para pembaca sebelumnya yang menyatakan, buku ini sangat memotivasi para pembacanya, yang mana motivasi menurut Donald dalam Sardiman (2012:73) menyatakan, "Motivasi adalah perubahan energi dalam diri seseorang yang ditandai munculnya "Felling" dan didahului dengan tanggapan terhadap adanya tujuan". Motivasi yang banyak disampaikan di dalam buku ini sejalan dengan tujuan persuasif yang bersifat mempengaruhi. Maka penulis tertarik untuk menganalisis teknik persuasif yang digunakan seorang Andrias Harefa di dalam bukunya yang berjudul Sukses Tanpa Gelar, pembaca akan menemukan lima belas kisah. Edisi awalnya hanya berisi tujuh kisah denga tokohtokoh inspirstif. Mereka telah melewati proses yang luar biasa sulit, namun berhasil membangkitkan roh keberhasilan di dalam dirinya. Lewat pemaparan yang singkat namun mengenai kisah-kisah tokoh-tokoh tersebut bisa memberikan gairah dan optimisme bagi siapa saja yang ingin sukses dengan atau tanpa gelar mampu membuat pembacanya termotivasi dengan menghasilkan kata-kata motivasi yang mampu mempengaruhi para pembacanya. Terlebih lagi buku pertama karangan Andrias Harefa termasuk ke dalam katagori buku Best Seller.

\section{METODOLOGI PENELITIAN}

Penelitian ini merupakan cara ilmiah untuk mendapatkan data dengan tujuan dan kegunaan tertentu (Sugiono, 2014: 3). Penelitian ini menggunakan metode deskriptif.Metode deskripsif adalah penelitian yang dimaksudkan untuk menyelidiki keadaan, kondisi atau hal-hal lain yang sudah disebutkan, yang hasilnya dipaparkan dalam bentuk laporan penelitian (Arikunto, 2013: 3). Jenis penelitian yang penulis lakukan ini adalah jenis penelitian perpustakaan, 
maksudnya penulis memperoleh data dari perpustakaan dengan cara mengumpulkan buku-buku yang berhubungan dengan masalah yang akan ditelitioleh penulis. Menurut Hamidy (2003:24) menyatakan, "Study perpustakaan atau library research, biasanya lebih banyak dilakukan untuk metode kualitatif'. Penulis menggunakan pendekatan kualitatif, karena dalam jenis penulisan ini tidak menggunakan angka-angka atau rumus statistik. Hamidy (2003:23) menyatakan, "Pendekatan kualitatif adalah Pendekatan yang memperhatikan segi-segi kualitas: sifat, keadaan, peran (fungsi) sejarah dan nilainilai”. Sementara Sumarta (2013:12) mengatakan, "Penelitian kualitatif yang diutamakan bukan kuantitatif berdasarkan angka-angka tetapi kedalam penghayatan terhadap interaksi antarkonsep yang sedang dikaji secara empris".

\section{HASIL DAN PEMBAHASAN}

Penelitian ini merupakan hasil reduksi data melalui proses identifikasi data, klasifikasi data dan kodefikasi data dengan berpedoman pada teori teknik persuasif menurut Keraf (2004). Deskripsi data berikut ini penulis kutip dari objek penelitian berupa buku Sukses Tanpa Gelar karya Andrias Harefa. Deskripsi data penulis sajikan berdasarkan urutan teknik persuasif. Adapun bab dari buku dalam penelitian ini yaitu: Bagian pertama Perjalanan ke dalam diri, pada bagian ini mengajak pembaca untuk memikirkan makna sukses bagi diri sendiri, yakni sukses pada level pribadi. Mencari makna sukses berarti melakukan perjalanan ke dalam diri sendiri. Mencari makna sukses berarti menguji dan mengevaluasi social mirror (pandanganpandangan atau label yang diberikan masyarakat dan orang-orang luar mengenai diri kita pribadi) yang acap kali buram dan gagal memantulkan realitas kebenaran yang sejati. Bagian kedua Lima Belas Orang "Gila" yang Sukses, pada bagian kedua memberikan contoh-contoh dari kehidupan nyata, yang terdapat lima belas tokoh yang meraih sukses dengan caranya masing-masing dan pada bidang pilihannya masing-masing. Satu dari lima belas contoh orang sukses dalam buku ini memiliki gelar sarjanaan. Namun gelar bukanlah faktor penentu utama yang membuat ia berhasil, sementara kisahnya sendiri terlalu bagus untuk tidak dimasukkan. Dan bagian ketiga Membangkitkan Roh Keberhasilan,. pada bagian ketiga atau terakhir memuat rahasia untuk sukses tanpa memiliki gelar, mengalahkan roh memiliki dengan cara membangkitkan roh keberhasilan. Di sini ingin ditegaskan bahwa faktor-faktor penentu sukses sejati itu bukanlah atribut-atribut "fisik" seperti gelar akademis, jabatan, uang, dan sebagainya.Tetapi lebih dari itu.Ia mencakup pemahaman mengenai kebenaran mengenai keberadaan manusia dan segala potensinya, keyakinan dan peta mental (paradigma) seseorang, serta komitmennya untuk mengembangkan kebiasaan dan karakter yang selaras nilai-nilai kebenaran yang dipahaminya. Sukses yang sejati itu memanusiakan manusia. Data yang diperoleh, diberi kode dan dikelompokkan ke dalam satu jenis teknik persuasif. Adapun kode tersebut mengikuti aturan sebagai berikut (teknik persuasif/halaman/ pargaraf/kalimat). Berdasarkan hasil bacaan buku Sukses Tanpa Gelar Karya Andrias Harefa diperoleh data Rasionalisasi(RS) sebanyak data, Identifikasi (ID) data, Sugesti (SG) sebanyak data, Konformitas (KN) sebanyak data, Kompensasi (KM) sebanyak data, Penggantian (PG) sebanyak data, dan Proyeksi (PY) sebanyak data.

\section{Rasionalisasi}

Rasionalisasi menurut Keraf (2004:124) adalah proses penggunaan akal untuk memberikan suatu dasar pembenaran suatu masalah, di mana dasar atau alas an itu tidak merupakan sebab langsung dari masalah itu. Rasionalisasi yang digunakan Andrias Harefa dalam buku "Sukses Tanpa Gelar pada bagian 1 Perjalanan ke dalam diri terdapat dikalimat:

(1) Sukses berarti memiliki wismo atau rumah. Rumah yang makin banyak atapnya, makin luas tanahnya, makin megah bangunannya berarti makin sukseslah ia. Kalau rumah masih kontrakan atau belum lunas cicilannya, atau luasnya kurang dari lapangan bola, masih jauhlah ia dari sukses. (RS/1/20/3/1). 
Kutipan diatas penulis peroleh dari kalimat Andrias Harefa di dalam buku Sukses Tanpa Gelar yang ditemukan pada bagian 1, halaman 20, paragraph 34 kalimat 1, dengan kode RS/1/20/3/1. Data tersebut termasuk ke dalam rasionalisasi karena Andrias Harefa memberikan dasar pembenaran secara logis bahwa Sukses berarti memiliki wismo atau rumah.

\section{Identifikasi}

Identifikasi yaitu mengidentifikasi diri penulis untuk menciptakan dasar umum pemikiran sama. Identifikasi yang digunakan Andrias Harefa dalam buku "Sukses Tanpa Gelar" pada bagaian 1 Perjalanan ke dalam diri terdapat dikalimat:

(2) Ia lahir di Gubuk, kota kecamatan kecil di Purwodadi, jawa tengah. Orangtuanya memiliki sebuah toko kelontong di dekat mrapen, yang tak bisa disebutr besar. (ID/2/ 35/1/1)

Data ID/2/ 35/1/1 di atas termasuk teknik persuasif identifikasi. Menurut Depdiknas identifikasi merupakan tanda kenal diri dan bukti diri. Andrias Harefa mengidentifikasi tanda kenal dirinya kepada pembaca. Bukti identifikasi pada kutipan di atas ialah Ia lahir di Gubuk, kota kecamatan kecil di Purwodadi, jawa tengah. Kalimat yang tercetak miring berkaitan dengan identifikasi yang berisi tanda kenal diri penulis. Jadi, identifikasi yang dimaksud dalam kalimat di atas diguanakan untuk mengidentifikasi beberapa hal yang berhubungan antara penulis dan pembaca.

\section{Sugesti}

$\begin{array}{rrc}\text { Sugesti menurut } & \text { Keraf (2004:126) } \\ \text { adalah suatu usaha membujuk atau }\end{array}$ mempengaruhi orang lain untuk menerima suatu keyakinan atau pendirian tertentu tanpa memberikan suatu dasar kepercayaan yang logis pada orang yamg ingin dipengaruhi. Sugesti biasa ditampilkan dengan rangkaian kata-kata yang menarik dan meyakinkan serta biasanya ditandai dengan penggunaan gaya bahasa personafikasi dan hiperbola untuk menyentuh hati pembaca. Sugesti yang digunakan Andrias Harefa dalam buku "Sukses Tanpa Gelar " pada bagian 1 terdapat dikalimat:

(3) Lebih baik bertindak, walau kelak terbukti tindakan itu salah dari pada takut bertindak dan karenanya tidak pernah melakukan sesuatu". (SG/1/14/4/3)

Data SG/1/14/4/3 Andrias Harefa menggunakan sugesti untuk mempengaruhi yang dapat menggerakkan hati orang; dorongan. Hal ini dapat dibuktikan ketika pengarang mengatakan "Lebih baik bertindak, walau kelak terbukti tindakan itu salah dari pada takut bertindak dan karenanya tidak pernah melakukan sesuatu". Kata yang bercetak miring berkaitan dengan sugesti karena kalimat tersebut mencoba mendorong dan ajakan kepada pembaca. Kalimat tersebut berusaha meyakinkan pembaca tentang suatu keputusan yang kita ambil sangatlah penting. Jadi, sugesti dalam kalimat di atas digunakan untuk mempengaruhi pembaca tanpa memberikan suatu dasar kepercayaan yang logis terhadap pembaca.

\section{Konformitas}

Konformitas menurut Keraf (2004:128) adalah suatu mekanisme mental untuk menyesuaikan diri atau mencocokan diri dnegan sesuatu yang diinginkanya. Konformitas biasanya digunakan dengan cara menunjukkan tindakan yang pernah dilakukan untuk mempengaruhi pembaca. Konformitas yang digunakan Andrias Harefa falam buku "Sukses Tanpa Gelar" pada bagian 2 terdapat dikalimat:

(4) Manusia yang satu ini memiliki pandangan yang unik mengenai kegagalan. Ia pernah berkata; "Tidak penting berapa kali Anda gagal, yang penting berapa kali anda bangkit". (KN/2/73/6/2)

Kutipan di atas penulis peroleh dari kalimat Andrias Harefa di dalam buku Sukses Tanpa Gelar yang ditemukan pada bagian 2, halaman 73 , paragraph 6 , kalimat 2 , dengan kode KN/2/73/6/2. Data tersebut termasuk ke dalam konformitas karena Andrias Harefa berusaha mencocokan diri dengan cara menunjukan tindakan yang pernah dilakukan untuk memengaruhi pembaca bahwa tindkan yang 
dilakukan Andrias Harefa Manusia yang satu ini memiliki pandangan yang unik mengenai kegagalan. Ia pernah berkata; "Tidak penting berapa kali Anda gagal, yang penting berapa kali anda bangkit". Kalimat yang bercetak miring berkaitan dengan konformitas. Jadi, konformitas yang dimaksud dalam kalimat di atas diartikan sebagai suatu keinginan atau tindakan yang dimiliki seseorang untuk mengubah dirinya sama dengan sesuatu yang lain sehingga pembaca memahaminya.

\section{Kompensasi}

Kompensasi menurut Keraf (2004:129) adalah kompensasi yaitu suatu tindakan atau suatu hasil dari usaha untuk mencari suatu penggantian (subtitut) bagi suatu hal yang tidak dapat diterima, atau suatu sikap atau keadaan yang tidak dapat dipertahankan. Kompensasi yang digunakan Andrias Harefa dalam buku "Sukses Tanpa Gelar" pada bagian 2 Lima Belas Orang "Gila" yang Sukses terdapat di kalimat:

(5) Sebelum berhasil mencapai citacitanya, untuk bertahan hidup ia rela menjadi tukang cuci piring direstoran. Lalu menjadi pembawa bundel-bundel koran yang dijual di stasiun-stasiun kereta api bawah tanah, karena duitnya lebih banyak. (Harefa, 2005, SOJDNY)

Kutipan di atas penulis peroleh dari kalimat Andrias Harefa di dalam buku Sukses Tanpa Gelar yang ditemukan pada bagian 2, halaman 35-36, paragraph 3, kalimat 1 , dengan kode $\mathrm{KM} / 2 / 35-36 / 3 / 1$. Data tersebut termasuk ke dalam kompensasi karena Andrias Harefa berusaha mencari penggantian Sebelum berhasil mencapai cita-citanya, untuk bertahan hidup ia rela menjadi tukang cuci piring direstoran. Lalu menjadi pembawa bundel-bundel koran yang dijual di stasiunstasiun kereta api bawah tanah, karena duitnya lebih banyak.

\section{Penggantian}

Penggantian menurut Keraf (2004:130) adalah suatu proses yang berusah menggantikan suatu maksud atau hal yang mengalami rintangan dengan suatu maksud atau hal yang sekaligus juga menggantikan emosi kebencian asli, atau kadang-kadang emosi cinta kasih yang asli. Pengganti yang digunakan Andrias Harefa dalam buku "Sukses Tanpa Gelar" pada bagian 1 Perjalanan ke dalam diri terdapat dikalimat:

(6) Sedangkan garwo, mungkin masih berlaku juga bagi lelaki. Namun wanita yang memiliki banyak lelaki masih belum positif citranya dimasyarakat kita. (PG/1/21/5/4)

Pada data PG/1/21/5/4 Andrias Harefa mengadakan penggantian terhadap suatu hal yang mengalami rintangan dengan maksud lain bahwa sedangkan garwo, mungkin masih berlaku juga bagi lelaki. Akibatnya, Andrias Harefa mengadakan penggantian Namun wanita yang memiliki banyak lelaki masih belum positif citranya dimasyarakat kita. Kata yang bercetak miring berkaitan dengan penggantian yang dimaksudkan dalam kalimat di atas digunakan untuk menggantikan suatu maksud yang mengalami rintangan dengan maksud lain sehingga pembaca memahaminya.

\section{Proyeksi}

Proyeksi menurut Keraf (2004:131) adalah suatu teknik untuk menjadikan sesuatu yang tadinya subjek menjadi objek. Semua sifat atau watak yang memiliki seseorang, tidak mau diakui lagi sebagai sifat atau wataknya, tetapi dilontarkan sebagai sifat atau watak orang lain. Proyeksi yang digunakan Andrias Harefa dalam buku "Sukses Tanpa Gelar" pada bagian 2 terdapat di kalimat:

(7) "Nubuat" ibunya menjadi kenyataan. Ia anak pintar yang dikenal orang. Semua kata ayahnya ternyata salah. Tekadnya makin bulat untuk membuktikan bahwa, " Aku bukan anak bodoh, bukan pembawa sial, bukan anak kurang ajar. Aku anak pintar dan dunia menganal namaku seperti kata ibu”. (PY/2/56/11/1)

Kutipan di atas penulis peroleh dari kalimat Andrias Harefa di dalam buku Sukses Tanoa Gelar yang ditemukan pada bagian 2, halaman 56 , paragraf 11 , dan kalimat 1 , dengan kode $\mathrm{PY} / 2 / 56 / 11 / 1$. Data tersebut termasuk ke dalam proyeksi karena Andrias Harefa berusaha untuk menjadikan suatu tadinya 
adalah subjek menjadi objek, terlihat dari yang

awalnya Nubuat adalah subjek berusaha menajdikan dirinya sebagai objeknya dengan cara menceritakan kehebatan dari dirinya, terlihat dari pernyatan Nubuat tekadnya makin bulat untk membuktikan bahwa, "Aku bukan anak bodoh, bukan pembawa sial, bukan anak kurang ajar. Aku anak pintar dan dunia menganal namaku seperti kata ibu”.

\section{SIMPULAN}

Berdasarkan analisis data yang penulis lakukan maka dapat disimpulkan hasil penelitian tentang teknik persuasif Andrias Harefa dalam buku Sukses Tanpa Gelar, sebagai berikut: 1. Teknik persuasif rasionalisasin yang digunakan oleh Andrias Harefa untuk memengaruhi pembaca lebih banyak memberikan pembenaran terhadap suatu hal dengan menggunakan alasan yang logis, dari pada untuk menipu diri sendiri atau orang lain. Teknik rasionalisasi digunakan Andrias Harefa dalam buku Sukses Tanpa Gelar sebanyak 3 data atau setara dengan $7 \%$ dari data keseluruhan, 2. Teknik persuasif yang digunakan oleh Andrias Harefa untuk memengaruhi pembaca dengan cara mengidentifikasi diri penulis untuk menciptakan dasar umum pemikiran yang sama antara penulis dan pembaca. Adapun penanda dari identifikasi ini yaitu penggunaan kata kita dan penyampaian identitas untuk menunjukan dirinya sama dengan pembaca. Identifikasi digunakan Andrias Harefa dalam buku Sukses Tanpa Gelar dengan jumlah 31data atau setara dengan $67 \%$ dari data keseluruhan, 3. Teknik persuasif sugesti yang digunakan oleh Andrias Harefa untuk memengaruhi pembaca dengan cara menggunakan kata-kata yang menarik dan meyakinkan. Penanda untuk teknik sugesti di temukan dalam bentuk kata-kata motivasi yang di rangkai dalam kata-kata yang indah dan meyakinkan pembaca. Sugesti yang digunakan Andrias Harefa dalam buku Sukses Tanpa Gelar dengan jumlah 2 data atau setara dengan 4\% dari data keseluruhan, 4. Teknik persuasif konformitas yang digunakan oleh Andrias Harefa untuk memengaruhi pembaca dengan cara menggunakan bukti bahwa Andrias Harefa telah melakukan tindakan sesuai dengan yang disampaikan kepada pembaca. Penanda untuk konformitas ditemukan dalam bentuk penyampaian pengalaman Andrias Harefa. Konformitas yang digunakan Andrias Harefa dalam buku Sukses Tanpa Gelar dengan jumlah 4 data atau setara dengan 9\% dari keseluruhan, 5. Teknik persuasif kompensasi yang digunakan oleh Andrias Harefa untuk memengaruhi pembaca dengan cara mencari penggantian untuk sesuatu yang tidak dapat dipertahankan. Penanda untuk kompensasi ini yaitu terdapat tindakan untuk kearah yang lebih baik. Kompensasi yang digunakan Andrias Harefa dalam buku Sukses Tanpa Gelar dengan jumlah 3 data atau setara dengan $7 \%$ dari data keseluruhan, 6. Teknik persuasif penggantian yang digunakan oleh Andrias Harefa untuk memengaruhi pembaca dengan cara menggunakan proses yang berusaha menggantikan suatu maksud atau hal yang mengalami rintangan dengan suatu maksud atau hal lain yang sekaligus juga menggatikan emosi kebencian asli, atau kadang-kadang emosi cinta kasih yang asli biasanya ditandai dengan penggantian situasi yang berhubungan dengan perasaan. Penggantian yang digunakan Andrias Harefa dalam buku Sukses Tanpa Gelar dengan jumlah 3 data atau setara dengan 7\% dari data keseluruhan, dan 7. Teknik persuasif proyeksi yang digunakan oleh Andrias Harefa untuk memengaruhi pembaca dengan cara menggunakan suatu teknik untuk menjadikan sesuatu yang tadinya adalah subjek menjadi objek atau sesuatu sifat atau watak yang dimiliki seseorang, tidak mau diakui lagi sebagai sifat atau wataknya, tetapi dilontarkan sebagai sifat dan watak orang lain. Biasanya ditandai dengan pendeskripsian seseorang. Proyeksi yang digunakan Andrias Harefa dalam buku Sukses Tanpa Gelar dengan jumlah 1 data atau setara dengan $2 \%$ dari data keseluruhan.

\section{REFERENSI}

Abidin, Yusuf Zainal.2013. Pengantar Retorika. Bandung: Pustaka Setia.

Aminah, Siti. 2015. "Teknik Persuasif dalam Buku Chairul Tanjung Si Anak Singkong Karya Tjahja Gunawan diredja". Skripsi. Pekanbaru: Universitas Islam Riau. 
Andrias Harefa. 2005. Sukses Tanpa Gelar. Jakarta: Gramedia Pustaka Utama.

Anwar, Gentasri.2013. Retorika Praktis Teknik dan Seni Berpidato. Jakarta : PT Rineka Cipta

Arikunto, Suharsimi. 2013. Prosedur Penelitian Suatu Pendekatan Pratik. Jakarta: Rineka Cipta.

Arsyad, Maidar. G., dan U. S., Mukti.1998. Pembinaan Kemampuan Berbicara Bahasa Indonesia. Jakarta: Erlangga.

Depdiknas.2008. Kamus Besar Bahasa Indonesia. Jakarta: Gramedia Pustaka Utama.

Faizah, Hasnah. (2007). Retorika. Pekanbaru: Insani Cendika.

Hamidy, UU. 2003. Metode Penelitian: Displin ilmu-ilmu Sosial dan Budaya. Pekanbaru: Bilik Kreatif Press

Hanafi, Abdullah Halim. 2011. Metode Penelitian Bahasa. Jakarta: Diadit Media Press.

Hendrikus, Dori Wuwur. 2009. Retorika Keterampilan Berpidato, Berdiskusi, Berargumentasi, Bernegosiasi. Yogyakarta: Kanisius

Keraf, Gorys. 2005. Argumentasi dan Narasi. Jakarta: Gramedia

Luhukay, Marsefio S. 2007. Jurnal Ilmiah SCRIPTURA ISSN 1978-385X. Surabaya.

Maarif, Zainul. 2001. Retorika Metode dan Praktik. Gramedia: Jakarta.

Moleong, Lexy. 2007. Metodologi Pennelitian Kualitatfi. Bandung: Remaja Rosdakarya.

Muslich, Mansur. 2010. Bahasa Indonesia pada Era Globalisasi: Kedudukan, Fungsi, Pembinaan, dan pengembangan. Jakarta: Bumi aksara.

Rahmat, Jalaluddin. 2011. Retorika Modern Pendekatan Praktis. Bandung: Remaja Rosdakarya.

Sardiman. 2012. Interaksi dan Motivasi Belajar Mengajar. Jakarta: PT Raja Grasindo Persada.

Sugiyono. 2014. Metode Penelitian Pendidikan, Pendekatan Kuantitatif, Kualitatif, dan $R \& D$. Bandung: Alfabeta.
Suhandang, Kustadi. 2008. Retorika Strategi Teknik dan Taktik Pidato. Bandung: Nuansa.

Sukarno, 2013. "Retorika Persuasi Sebagai Upaya Mempengaruhi Jamaah Pada Teks Kotbah Jumat". Jurnal Humaniora, Volulme 25, No. 2; ISSN: 2302-9269.

Sumartini. 2015. "Teknik Persuasif dalam Buku Berani Gagal Karya Billi P.S Lim”. Skripsi. Pekanbaru: Universitas Islam Riau.

Tarigan. Hendry Guntur. 2008. Berbicara Sebagai Suatu Keterampilan Berbahasa. Bandung: Angkas.

Triandjojo, Indriani. 2012. "Retorika Dalam Iklan Di Media Cetak Indonesia". Jurnal Majalah Ilmiah Informatika, Volume 3, No .1;ISSN: 1411-6413. 